\title{
Screening, production and partial characterization of proteases from microbial isolates obtained from waste dumpsites
}

\author{
Amos Ndarubu Tsado*1,2, Evans Chidi Egwim², Solomon Bankole Oyeleke ${ }^{3}$ and Oluwatosin \\ Kudirat Shittu²
}

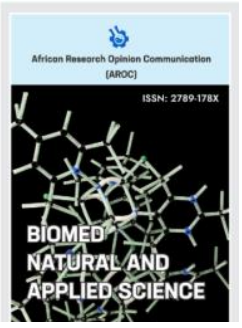

\author{
${ }^{1}$ Department of Biological Science, Niger State Polytechnic, Zungeru, Niger State, Nigeria \\ ${ }^{2}$ Department of Biochemistry, School of Life Science, Federal University of Technology, Minna, Nigeria \\ ${ }^{3}$ Department of Microbiology, Federal University of Technology, Minna, Nigeria
}

Correspondence should be addressed to T.A.N; Email: infoamosndarubu@gmail.com

https://doi.org/10.53858/bnas01024553

\begin{abstract}
Background: Proteases are proteolytic enzymes having a wide range of applications in various industries such as the food industry, pharmaceutical industry, medicine, leather and textile. Microorganisms are considered potentially to be the most suitable sources of proteases. Prior to industrial applications of proteases, it is important to investigate physical parameters affecting their enzyme activities. Methods: The microorganisms isolated from different waste dumpsites were screened for proteolytic activity using casein as a substrate. The optimum temperature and $\mathrm{pH}$ and kinetic parameters such as $\mathrm{K}_{\mathrm{m}}, \mathrm{V}_{\max }$, specific activities and $\mathrm{K}_{\mathrm{cat}}$ of the proteases produced were determined to ascertain their industrial prospects. Results: The results obtained showed that $A$. niger, A. flavus, Penicillium sp, Muccor and Fusarium sp. are the active protease producing fungal isolates while $B$. subtilis and $B$. megaterium are the active protease producing bacterial isolates obtained from waste dumpsites. The optimum temperature and $\mathrm{pH}$ values of the proteases produced from these isolates were recorded within a close range of $50-60{ }^{\circ} \mathrm{C}$ and $8-9$ respectively. The protease produced from Penicillium $s p$ isolated from sewage sludge was observed to have maximum $V_{\max }(222.2 \mathrm{U} / \mathrm{ml})$ while protease produced from $B$. subtilis isolated from domestic waste dumpsite was recorded to have the minimum $\mathrm{K}_{\mathrm{m}}$ value $(0.244 \mathrm{mg} / \mathrm{ml})$. The protease produced from $B$. megaterium isolated from the abattoir site was observed to have the highest specific activity $(659.02 \mathrm{U} / \mathrm{mg})$ while the protease produced from $B$. subtilis isolated from refuse dumpsite was observed to have a maximum $\mathrm{K}_{\text {cat }}$ value $\left(26.42 \mathrm{~s}^{-1}\right)$. Conclusion: These results show that proteases produced by the isolates obtained from; abattoir sites, refuse waste dumpsite, sewage sludge, domestic waste dumpsites, possess remarkable kinetic parameters that are crucial for their industrial applications

Keywords: Protease; waste dumpsites; microorganism; Km, Vmax; Kcat

Received: 15 June 2021, Revised: 08 August 2021, Published: 19 September 2021

Citation: Tsado, A. N., Egwim, E.C., Oyeleke, S.B., and Shittu, O.K., (2021). Screening, production and partial characterization of proteases from microbial isolates obtained from waste dumpsites. BIOMED Natural and Applied Science,1(2):45-53, https://doi.org/10.53858/bnas01024553
\end{abstract}

\subsection{Introduction}

The global market for industrial enzymes increased from $\$ 2.2$ billion in 2006 to $\$ 2.3$ billion in 2007, $\$ 2.7$ billion in 2012 and $\$ 4.9$ billion in 2013 [1]. Proteases are a group of enzymes with a wide range of applications and account for $40-60 \%$ of the total enzyme sales. Proteases refer to a group of enzymes whose catalytic function is to hydrolyze peptide bonds of proteins [2]. They are also called proteolytic enzymes or proteinases. Proteases form a large group of enzymes belonging to the class of hydrolases. They are ubiquitous in nature and perform a major role with respect to their applications in both physiological and commercial fields [3].

They are used extensively in the detergent, leather, pharmaceutical, and food industries. Proteases found in the market is mostly produced by microorganisms although there are some produced by plants and animals [4]. The total value of protease covers $60 \%$ of the total worldwide enzyme sales [5]. This is because microbial properties exhibit advantageous properties that are useful for biotechnological processes such as their resilience under extreme temperature, $\mathrm{pH}$ and the presence of inhibitors [6]. The high demand for proteases in industries brings the attention of researchers to explore novel sources 
for proteases where isolation, screening and characterization of new promising strains are a continuous process [4]. Several waste dumpsites have been reported to be good sources of microorganisms of various industrial importances. Some of these wastes dumpsites include sewage sludge [7], domestic waste dumpsite, refuse waste dumpsite [4], and abattoir [8].

Wastes may be generated during the extraction of raw materials, the processing of raw materials into intermediate and final products, the consumption of final products from households, and other human activities [9]. When waste is dumped on land, microorganisms such as bacteria and fungi proliferate using the components of the waste materials as a source of nutrients for growth as well as degrading the organic materials in the waste [10]. These microorganisms degrade wastes (mainly, the organic part) through their metabolic processes and this property of microbes has been exploited in bioprocess technology [11].

The composition of waste dumpsites is very complex because it includes various constituents of different origins. A dumpsite constituent is largely dependent on the location, such as nearness to household, industry and marketplace [9]. All these waste substances are chemically comprised of fats, cellulose, starch, lipids, protein, and other organic matter. The moisture and salt contents lead to rapid decomposition of the organic contents in the wastes by microorganisms thus produce unpleasant odours [12].

Therefore, the growth of microorganisms on the protein components of waste and their subsequent degradation makes them a possible site for the isolation of protease producing isolates [13]. Waste harboring these microorganisms can contaminate surface water, groundwater, soil and air. Hence, the objective of this study was to identify the microorganisms associated with waste dump sites with inherent properties of industrial protease enzyme production.

\subsection{Materials and Methods}

\subsection{Sample collections}

This study was carried out in Minna, Niger State Nigeria. Niger State is located between latitudes $9^{\circ} 37^{\prime} \mathrm{N}-$ $9^{\circ} 79^{\prime} \mathrm{N}$ and longitude $6^{\circ} 16^{\prime} \mathrm{E}-6^{\circ} 65^{\prime} \mathrm{E}$. Samples were collected from refuse, sewage sludge, domestic, abattoir soils and Cow rumen ingesta in a sterile polythene bag and immediately brought to the laboratory for the isolation of fungi and bacteria.

\subsection{Media, chemicals and reagents}

Nutrient agar (NA), glucose, $0.87 \%$ sodium saline, $1 \% \mathrm{CaCO}_{3}, 70 \%$ and $95 \%$ alcohol, crystal violet $(0.1 \mathrm{~g})$, gram's iodine $(0.18 \mathrm{~g})$, saffranine $(0.2 \mathrm{~g})$, glycerine, $3 \% \mathrm{KOH}$, Malachite green $(0.5 \mathrm{~g})$, carbolfuchsin stain, hydrochloride acid (conc. $3 \mathrm{ml}$ ), methylene blue chloride $(0.3 \mathrm{~g})$ beef extract $(0.3 \%)$, zinc chloride $(1 \mathrm{~g})$, potassium iodine $(0.1 \mathrm{~g})$, powdered zinc metal, yeast extract $(0.5 \mathrm{~g}), \mathrm{MgSO} 4(0.02 \mathrm{~g})$, K2HPO4 $(0.1 \mathrm{~g}), \mathrm{NaCl}(0.5 \mathrm{~g})$, methyl red $(0.008 \mathrm{~g})$, tryptone $(1 \mathrm{~g})$, potassium phosphate $(0.5 \%)$, sodium citrate $(0.2 \mathrm{~g})$, agar $(1.5 \mathrm{~g})$, bromomethyl blue $(0.08 \mathrm{~g}),(\mathrm{NH} 4) \mathrm{H} 2 \mathrm{PO} 4(0.1 \mathrm{~g})$.

\subsection{Isolation of microorganisms}

One gram (1gm) of the soil sample from each dumpsite and cow rumen ingesta was mixed with $9 \mathrm{ml}$ of saline solution (Master dilution) and $1 \mathrm{ml}$ of the solution was serially transferred to tubes containing 9 $\mathrm{ml}$ saline each so that for each transfer the suspension was diluted 10times. Each tube was shaken vigorously. $0.1 \mathrm{ml}$ solution was spread to Petri plates containing sterilized nutrient agar and saboroud dextrose agar for bacterial and fungal isolation. The pure isolates were stored in bottles for further studies.

\subsection{Morphological and biochemical identification of bacteria isolates}

The pure cultures were identified based on their cultural, morphological, and Biochemical test (Indole, Voges-Proskauer, methyl red, citrate utilization, catalase, nitrate reduction, urease, sugar fermentation, and starch hydrolysis test as described by Makut and Ibrahim [14].

\subsection{Morphological and biochemical identification of fungi isolates}

Fungi isolates identification was carried out as described by Makut and Ekeleme [15]. Identification was based on microbiological standard procedure using cultural and morphological characteristics. The 
cultural characteristics were determined by their appearance on culture plates while the morphological features were determined microscopically using lactophenol in cotton blue staining technique.

\subsection{Screening for proteolytic activity}

The isolates obtained from some selected waste dumpsites were spread on Petri plates containing milk agar medium $(\mathrm{pH} 7)$ and incubated for 5 days at $25^{\circ} \mathrm{C}$ for fungal isolates and 24 hours at 37 oC for bacterial isolates. A clear zone of skim milk hydrolysis indicated protease producing organisms. Colonies showing proteolytic activity were selected for protease enzyme production [16].

\subsection{Production of protease}

Protease production was carried out by inoculating protease producing isolate into a basal medium $\left(\mathrm{NH}_{4} \mathrm{Cl}-0.5 \%, \mathrm{NaCl}-0.5 \%, \mathrm{CaCl}_{2}-0.2 \%, \mathrm{MgCl}_{2} .6 \mathrm{H}_{2} \mathrm{O}-0.2 \%, \mathrm{~K}_{2} \mathrm{HPO}_{4}-0.4 \%, \mathrm{KH}_{2} \mathrm{PO}_{4} 0.3 \%\right)$ containing $0.7 \%$ peptone and $0.5 \%$ as nitrogen and carbon source respectively. The mixture was adjusted to $\mathrm{pH}$ 7.5 and maintained at $37^{\circ} \mathrm{C}$ on a shaker at $250 \mathrm{revs} / \mathrm{min}$ for 96 hours [17].

\subsection{Determination of protease activity}

The activity of protease was assessed in triplicate by measuring the release of trichloroacetic-acid soluble peptides from $0.5 \%(\mathrm{w} / \mathrm{v})$ casein in Tris $-\mathrm{HCl}(\mathrm{pH} 9.0)$ at $60{ }^{\circ} \mathrm{C}$ for $10 \mathrm{~min}$. The $1 \mathrm{~mL}$ reaction was terminated by adding $0.5 \mathrm{~mL}$ of $10 \%$ trichloroacetic acid. It was left for $15 \mathrm{~min}$ and then centrifuged at $14000 \mathrm{~g}$ for $10 \mathrm{~min}$. One unit of enzyme activity was defined as the amount of enzyme required to release $1 \mu \mathrm{g}$ of tyrosine/min under standard conditions [18]. The specific activity of the enzymes produced from each isolate was computed. The Kcat values of the enzymes produced from each isolate were calculated as follows;

Kcat $=$ Enzyme activity $X$ Total protein concentration

\subsection{Characterization of proteases produced by microbial isolates from dumpsites}

\subsubsection{Effect of $\mathrm{pH}$ on protease activity}

The effect of $\mathrm{pH}$ on enzyme activity was carried out by incubating the reaction mixture at $40^{\circ} \mathrm{C}$ over a $\mathrm{pH}$ range of 4-9. This was achieved using various buffers at different $\mathrm{pH}$ ranges; $0.05 \mathrm{M}$ sodium citrate buffer ( $\mathrm{pH} \mathrm{4-6)}$ and $0.05 \mathrm{M}$ Tris- $\mathrm{HCl}(\mathrm{pH} \mathrm{7-9)}$. Then the enzyme activity was determined by the standard enzyme assay.

\subsubsection{Effect of temperature on protease activity}

The effect of temperature on enzyme stability was carried out by incubating the reaction mixture over a varied temperature of 30 to $80^{\circ} \mathrm{C}$ at a predetermined $\mathrm{pH}$. Then the enzyme activity was determined by the standard enzyme assay.

\subsubsection{Effect of substrate concentration on protease activity}

Effect of substrate concentration on protease activity was determined in reaction mixtures containing varied concentrations of casein solution $(\mathrm{mg} / \mathrm{ml}) ; 2.5,5.0,10.0,25.0,30.0,35.5$. Michaelis-Menten constant $(\mathrm{Km})$ and maximum velocity $(\mathrm{Vmax})$ of protease were calculated from the plotted graph of $1 / V_{0}$ against $[1 / \mathrm{S}]$.

\subsection{Statistical analysis}

Data collected were subjected to statistical analysis using the statistical package for social science version 21.0 and express as mean \pm standard error of mean (SEM). Statistical significance of the results between groups was determined using One-way analysis of variance (ANOVA) followed by Duncans multiple range test (DMRT). Differences in mean were considered to be significant at $p<0.05$.

\subsection{Results}

\subsection{Total microbial counts of the isolates from the selected dumpsites}

The Domestic, refuse and abattoir dump sites produced significantly $(p<0.05)$ higher bacteria counts $(x$ $10^{4} \mathrm{cfu} / \mathrm{g}$ ) of $138.33 \pm 4.67,120.33 \pm 5.67$ and $123.33 \pm 8.45$ when compared with the rumen ingesta 
$\left(87.00 \pm 3.45 \times 10^{4} \mathrm{cfu} / \mathrm{g}\right)$ and sewage sludge $\left(103.45 \pm 3.45 \times 10^{4} \mathrm{cfu} / \mathrm{g}\right)$. Higher fungi count $(28.33 \pm 4.56$ $\times 10^{4} \mathrm{cfu} / \mathrm{g}$ ) was produced from the refuse dump site when compared with other dumpsites (Table 1)

Table 1: Counts of the total bacterial and fungal isolates from the selected dumpsites

\begin{tabular}{|c|c|c|}
\hline Dump sites & Bacteria (x 10 $\left.0^{4} \mathrm{cfu} / \mathrm{g}\right)$ & Fungi (x 104 cfu/g) \\
\hline RDS 1 & $120.33 \pm 5.67^{c}$ & $28.33 \pm 4.56^{c}$ \\
\hline ABS 1 & $123.33 \pm 8.45^{c}$ & $1.33 \pm 0.33^{a}$ \\
\hline RMI 1 & $87.00 \pm 3.45^{\mathrm{a}}$ & $5.66 \pm 0.89^{b}$ \\
\hline SWS 1 & $103.45 \pm 3.45^{b}$ & $4.00 \pm 1.00^{b}$ \\
\hline DDS 1 & $138.33 \pm 4.67^{d}$ & $25.66 \pm 4.56^{c}$ \\
\hline
\end{tabular}

Data are Mean \pm SEM of triplicate determinations. Values followed by different superscript alphabets are significantly different $(p<0.05)$. RDS; Refuse Dump Site, ABS; Abattoir Site, RMI; Rumen Ingesta, SWS; Sewage Sludge, DDS; Domestic Dump Site.

\subsection{Occurrence frequencies of microbial isolates from the selected dumpsites}

The occurrence frequencies of fungal and bacterial isolates from the selected dumpsites are shown in Tables 2 and 3 respectively. The fungi isolates have frequencies of occurrence in the order of Aspergillus niger > Penicillin spp. > Aspergillus flavus $>$ Saccharomyces cerevisiae > Mucor sp. $>$ Trichophyton sp. $>$ Fusarium sp. (Table 2) while the bacteria isolates have frequencies of occurrence in the order of Bacillus subtilis $>$ Staph. Aureus $>$ P. aeruginosa $>$ Strep. Feacilis $>$ Bacillus megaterium $>$ E. coli $>$ Staph. Epidermidis $>$ K. pneumonia $>$ B. cereus (Table 3)

Table 2: Occurrence frequencies of fungal isolates from the selected dumpsites

\begin{tabular}{|l|l|l|l|l|l|l|l|}
\hline \multicolumn{1}{|c|}{ Isolates } & $\begin{array}{c}\text { Aspergillus } \\
\text { niger }\end{array}$ & $\begin{array}{c}\text { Aspergillus } \\
\text { flavus }\end{array}$ & $\begin{array}{c}\text { Penicillin } \\
\text { Sp. }\end{array}$ & $\begin{array}{c}\text { S. } \\
\text { cerevisiae }\end{array}$ & \multicolumn{1}{l}{ Trichophyton } \\
sp. & \multicolumn{1}{c|}{$\begin{array}{c}\text { Mucor } \\
\text { sp. }\end{array}$} & $\begin{array}{c}\text { Fusarium } \\
\text { sp. }\end{array}$ \\
\hline RDS(17.65) & $1(16.7)$ & $2(33.3)$ & $1(16.7)$ & $2(33.3)$ & $0(0.0)$ & $0(0.0)$ & $0(0.0)$ \\
\hline ABS(11.76) & $1(25.0)$ & $0(0.0)$ & $0(0.0)$ & $0(0.0)$ & $1(25.0)$ & $2(50.0)$ & $0(0.0)$ \\
\hline RMI(29.41) & $3(30.0)$ & $2(20.0)$ & $3(30.0)$ & $0(0.0)$ & $0(0.0)$ & $1(10.0)$ & $1(10.0)$ \\
\hline SWS(23.53) & $1(12.5)$ & $1(12.5)$ & $2(25.0)$ & $2(25.0)$ & $1(12.5)$ & $1(12.5)$ & $0(0.0)$ \\
\hline DDS(17.65) & $2(33.3)$ & $1(16.7)$ & $1(16.7)$ & $1(16.7)$ & $1(16.7)$ & $0(0.0)$ & $0(0.0)$ \\
\hline Total & 8(23.5) & $6(17.6)$ & $7(20.6)$ & $5(14.7)$ & $3(8.8)$ & $4(11.8)$ & $1(2.9)$ \\
\hline
\end{tabular}

RDS; Refuse Dump Site, ABS; Abattoir Site, RMI; Rumen Ingesta, SWS; Sewage Sludge, DDS; Domestic Dump Site

\begin{tabular}{|c|c|c|c|c|c|c|c|c|c|}
\hline Isolates & $\begin{array}{c}\text { Staph. } \\
\text { epidermidis }\end{array}$ & $\begin{array}{c}\text { B. } \\
\text { subtilis }\end{array}$ & $\begin{array}{c}P . \\
\text { aeruginosa }\end{array}$ & E. coli & $\begin{array}{c}\text { K. } \\
\text { pneumonea }\end{array}$ & $\begin{array}{c}\text { B. } \\
\text { cereus }\end{array}$ & $\begin{array}{l}\text { Strep. } \\
\text { feacilis }\end{array}$ & $\begin{array}{c}\text { B. } \\
\text { megaterium }\end{array}$ & $\begin{array}{l}\text { Staph. } \\
\text { aureus }\end{array}$ \\
\hline $\begin{array}{c}\text { RDS } \\
(21.67) \\
\end{array}$ & $\begin{array}{c}1 \\
(7.7)\end{array}$ & $\begin{array}{c}3 \\
(23.1)\end{array}$ & $\begin{array}{c}3 \\
(23.1)\end{array}$ & $\begin{array}{c}0 \\
(0.0)\end{array}$ & $\begin{array}{c}1 \\
(7.7)\end{array}$ & $\begin{array}{c}0 \\
(0.0)\end{array}$ & $\begin{array}{c}1 \\
(7.7)\end{array}$ & $\begin{array}{c}2 \\
(15.4)\end{array}$ & $\begin{array}{c}2 \\
(15.4)\end{array}$ \\
\hline $\begin{array}{c}\text { ABS } \\
(18.33)\end{array}$ & $\begin{array}{c}2 \\
(18.2)\end{array}$ & $\begin{array}{c}3 \\
(27.3)\end{array}$ & 2 (18.2) & $\begin{array}{c}1 \\
(9.1)\end{array}$ & $\begin{array}{c}1 \\
(9.1)\end{array}$ & $\begin{array}{c}0 \\
(0.0)\end{array}$ & $\begin{array}{c}1 \\
(9.1)\end{array}$ & $\begin{array}{c}1 \\
(9.1)\end{array}$ & $\begin{array}{c}1 \\
(9.1)\end{array}$ \\
\hline $\begin{array}{c}\text { RMI } \\
(20.00) \\
\end{array}$ & $\begin{array}{c}1 \\
(8.3)\end{array}$ & $\begin{array}{c}2 \\
(16.7)\end{array}$ & $\begin{array}{c}0 \\
(0.00)\end{array}$ & $\begin{array}{c}1 \\
(8.3)\end{array}$ & $0(0.00)$ & $\begin{array}{c}0 \\
(0.0)\end{array}$ & $\begin{array}{c}2 \\
(16.7)\end{array}$ & $\begin{array}{c}1 \\
(8.3)\end{array}$ & $\begin{array}{c}5 \\
(41.7)\end{array}$ \\
\hline $\begin{array}{c}\text { SWS } \\
(21.67)\end{array}$ & $\begin{array}{c}1 \\
(7.7)\end{array}$ & $\begin{array}{c}2 \\
(15.4)\end{array}$ & $\begin{array}{c}1 \\
(7.7)\end{array}$ & $\begin{array}{c}3 \\
(23.1)\end{array}$ & $\begin{array}{c}2 \\
(15.4)\end{array}$ & $\begin{array}{c}3 \\
(23.1)\end{array}$ & $\begin{array}{c}0 \\
(0.0)\end{array}$ & $\begin{array}{c}0 \\
(0.00)\end{array}$ & $\begin{array}{c}1 \\
(7.7)\end{array}$ \\
\hline $\begin{array}{c}\text { DDS } \\
(18.33) \\
\end{array}$ & $\begin{array}{c}0 \\
(0.0)\end{array}$ & $\begin{array}{c}3 \\
(27.3)\end{array}$ & $\begin{array}{c}1 \\
(9.1)\end{array}$ & $\begin{array}{c}0 \\
(0.0)\end{array}$ & $\begin{array}{c}0 \\
(0.00)\end{array}$ & $\begin{array}{c}0 \\
(0.0)\end{array}$ & $\begin{array}{c}2 \\
(18.2)\end{array}$ & $\begin{array}{c}2 \\
(18.2)\end{array}$ & $\begin{array}{c}3 \\
(27.3)\end{array}$ \\
\hline Total & $\begin{array}{c}5 \\
(8.3)\end{array}$ & $\begin{array}{c}13 \\
(21.7)\end{array}$ & $\begin{array}{c}7 \\
(11.7)\end{array}$ & $\begin{array}{c}5 \\
(8.3)\end{array}$ & $\begin{array}{c}4 \\
(6.7)\end{array}$ & $\begin{array}{c}3 \\
(5.0)\end{array}$ & $\begin{array}{c}6 \\
(10.0)\end{array}$ & $\begin{array}{c}6 \\
(9.5)\end{array}$ & $\begin{array}{c}12 \\
(20.0)\end{array}$ \\
\hline
\end{tabular}

\subsection{Identification of the proteolytic microbial isolates from the selected dumpsites}

The biochemical characteristics of the proteolytic bacterial isolates identified from the selected dumpsites are shown in table 4 while the identity of the proteolytic fungi is shown in table 5 . Bacillus subtilis and Bacillus megaterium (Table 4) were identified as the proteolytic bacteria isolated from all the dumpsites while 3 fungi species including the Aspergillus niger, Penicillum sp, and Aspergillus flavus were the identified proteolytic fungi isolates from the selected dumpsites (Table 5) 
Table 4: Biochemical characteristic of the proteolytic bacterial isolates identified from the selected dumpsites

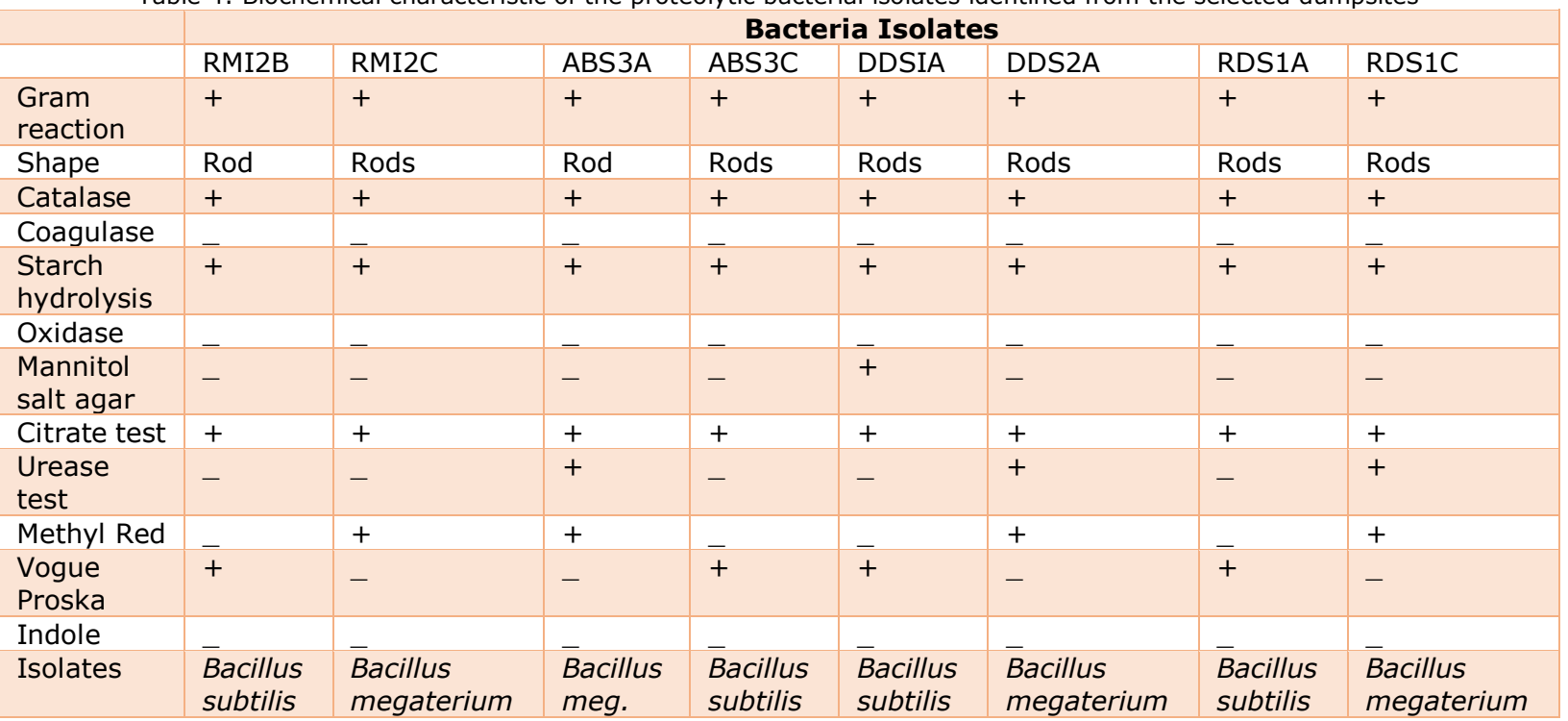

RDS; Refuse Dump Site, ABS; Abattoir Site, RMI; Rumen Ingesta, SWS; Sewage Sludge, DDS; Domestic Dump Site

Table 5: proteolytic fungi isolates identified from the selected dumpsites

\begin{tabular}{|ll}
\hline Sample Sites & Fungi \\
\hline RDS1G & Aspergillus niger \\
RDS1H & Penicillum $s p$ \\
SWS1D & Penicillin $s p .$, \\
SWS1E & Aspergillus flavus \\
RMI1B & Penicillin sp. \\
RMI1C & Aspergillus niger \\
\hline
\end{tabular}

RDS; Refuse Dump Site, SWS; Sewage Sludge, RMI; Rumen Ingesta

\subsection{Partial characterization of proteases produced by the microbial isolates}

The Partial characterization and kinetic parameters of proteases produced from dumpsites isolates are shown in table 6 . The optimum temperature and $\mathrm{pH}$ values of the proteases produced from these isolates were recorded within a close range of $50-60{ }^{\circ} \mathrm{C}$ and $8-9$ respectively. The protease produced from Penicillium $s p$ isolated from sewage sludge was observed to have maximum $V_{\max }(222.2 \mathrm{U} / \mathrm{ml})$ while protease produced from $B$. subtilis isolated from domestic waste dumpsite was recorded to have the minimum $\mathrm{K}_{\mathrm{m}}$ value $(0.244 \mathrm{mg} / \mathrm{ml})$. The protease produced from $B$. megaterium isolated from the abattoir site was observed to have the highest specific activity $(659.02 \mathrm{U} / \mathrm{mg})$ while the protease produced from $B$. subtilis isolated from refuse dumpsite was observed to have a maximum $\mathrm{K}_{\text {cat }}$ value $\left(26.42 \mathrm{~s}^{-1}\right)$

\begin{tabular}{|c|c|c|c|c|c|c|c|c|c|}
\hline Dumpsite & $\begin{array}{c}\text { Isolates } \\
\text { Code }\end{array}$ & $\begin{array}{l}\text { Opt. } \\
\text { pH }\end{array}$ & $\begin{array}{l}\text { Opt. } \\
\text { temp. } \\
\text { (oC) }\end{array}$ & $\begin{array}{c}\text { Vmax } \\
(\mathrm{U} / \mathrm{ml})\end{array}$ & $\begin{array}{c}\mathrm{Km} \\
(\mathrm{mg} / \mathrm{ml})\end{array}$ & $\begin{array}{l}\text { Activity } \\
(\mathrm{U} / \mathrm{ml})\end{array}$ & $\begin{array}{c}\text { Protein } \\
\text { concentration } \\
(\mathrm{mg} / \mathrm{ml})\end{array}$ & $\begin{array}{l}\text { Specific } \\
\text { activity } \\
(\mathrm{U} / \mathbf{m g})\end{array}$ & Kcat \\
\hline \multirow[t]{4}{*}{ RMI } & RMI2B & 9.0 & 50 & 111.11 & 0.345 & 86.04 & 0.30 & 286.80 & 25.81 \\
\hline & RMI2C & $7-9$ & 50 & 128.21 & 0.385 & 60.66 & 0.23 & 263.74 & 13.95 \\
\hline & RMI1B & 8 & 50 & 83.33 & 6.67 & 42.24 & 0.596 & 70.87 & 25.18 \\
\hline & RMI1C & 9 & 50 & 45.87 & 3.57 & 17.46 & 0.246 & 70.98 & 4.30 \\
\hline \multirow[t]{4}{*}{ RDS } & RDS1A & 9 & 50 & 166.67 & 0.333 & 90.78 & 0.291 & 311.96 & 26.42 \\
\hline & RDS1C & 9 & 40 & 166.70 & 0.730 & 79.38 & 0.286 & 277.55 & 22.70 \\
\hline & RDS1G & 9 & 50 & 38.48 & 0.455 & 23.34 & 0.404 & 57.77 & 9.43 \\
\hline & RDS1H & 9 & 50 & 62.50 & 9.09 & 35.76 & 0.440 & 81.27 & 15.73 \\
\hline \multirow[t]{2}{*}{ ABS } & ABS3A & 9 & $40-60$ & 71.48 & 0.313 & 40.20 & 0.061 & 659.02 & 2.45 \\
\hline & ABS3C & 9 & 50 & 90.91 & 0.413 & 75.06 & 0.261 & 287.57 & 19.59 \\
\hline \multirow[t]{2}{*}{ DDS } & DDS1A & 9 & 50 & 153.85 & 0.244 & 87.54 & 0.225 & 389.07 & 19.70 \\
\hline & DDS2A & 8 & 40 & 102 & 0.401 & 57.00 & 0.174 & 327.59 & 9.92 \\
\hline \multirow[t]{2}{*}{ SWS } & SWS1D & 9 & 50 & 222.22 & 3.33 & 19.20 & 0.509 & 37.72 & 9.77 \\
\hline & SWS1E & 8 & 50 & 11.63 & 2.11 & 11.58 & 0.224 & 51.70 & 2.46 \\
\hline
\end{tabular}

RDS; Refuse Dump Site, ABS; Abattoir Site, RMI; Rumen Ingesta, SWS; Sewage Sludge, DDS; Domestic Dump Site 


\subsection{Discussion}

Among the isolates obtained from all the dumpsites, the isolates that showed zone of clearance on skimmed milk agar plates were presented in table 4, for bacterial isolates and table 5, for fungal isolates. The zones of clearance shown by these isolates are indications of protein (casein in skimmed milk) hydrolysis by the protease produced by the isolates. This indicates that proteases producing isolates are present in refuge waste dumpsite, abattoir soil, domestic waste dumpsite, sewage sludge and cow rumen ingesta. The presence of these proteolytic isolates in these waste dumpsites depends greatly on the protein waste components arising from kitchen or food remnants [6].

These microorganisms (bacteria and fungi) are actively involved in the degradation of protein constituents of domestic waste, thereby making the dumpsite a natural habitat. They used the waste protein of these dumpsites as their major source of nitrogen for extracellular protease production required for further protein degradation [19]. Proteolytic microorganisms were also isolated by other researchers from landfills and biodegradable portions of domestic waste [19-21]. This present result suggests the previously listed waste dumpsites promising sources of proteolytic bacteria.

As shown in table 6, protease produced from Bacillus megaterium (ABS 3A), isolated from abattoir soil was recorded to have maximum specific activity $(659.02 \mathrm{U} / \mathrm{mg})$ while protease produced from $A$. flavus (SWS 1D) obtained from sewage sludge was recorded to have the lowest specific activity $(37.72 \mathrm{U} / \mathrm{mg})$. The specific activity of an enzyme is the amount of substrate converted by one unit of the enzyme protein. The specific activity of the protease produced from $B$. megaterium obtained from abattoir soil could be as a result of the protein waste components such as meat, bone, blood, hoof, horn, hair etc which are constantly present at the abattoir site. However, protease produced by $B$. megaterium (ABS3A) obtained from abattoir soil has minimum Kcat value (2.45).

This signifies that the protease has a minimum turnover rate of its substate (casein). Abattoir microorganisms are actively involved in the degradation of the protein constituent of abattoir soil, thereby making this site a natural habitat. Although $A$. flavus has been reported by many researchers to be an active protease producer, the low specific activity recorded in this study could be due to the site of isolation. Sewage sludge is low in protein waste content when compared with other sites (abattoir soil, domestic waste dumpsite, refuse waste dumpsite, and cow rumen ingesta) in this study.

Enzyme activities are highly dependent on $\mathrm{pH}$ and temperature. The active site of the enzymes must have the right conformations for the protein substrate to bind onto it. $\mathrm{pH}$ and temperature alteration are the common ways used to enhance the desirably of the enzymatic reaction. Generally, the enzyme works well within a range of temperatures specific to the organism. The reaction rates basically increase with an increase in temperature until a limit. At the limit temperature, the enzyme and protein will be denatured resulting from the breaking down of the weak ionic and hydrogen bonding that stabilize the three-dimensional structure of the enzyme active site, hence losing its secondary and tertiary structure [22].

The $\mathrm{pH}$ values for the proteases produced from all the isolates obtained from the waste dumpsite in this study were recorded around a close range of 8.0 to 9.0 as shown in table 6 . These results suggest waste dumpsites potential sources of alkaline proteases for industrial application. Therefore, proteases produced from waste dumpsites could be recommended in the detergent industry and leather industry which require majorly alkaline proteases for their industrial processes. The decline in enzyme activity could be a result of conformational change in protein three-dimensional structures at extreme $\mathrm{pH}$ values. The optimum catalytic activity from different proteases reported by previous researchers was in the range of $\mathrm{pH}$ 7-11 [22-24].

It was also very interesting to note that the optimum temperature values of the proteases produced from all the isolates obtained from waste dumpsites were recorded at $50{ }^{\circ} \mathrm{C}$ (table 6 ). Beyond these optimum values, the activities of the proteases were observed to decline. The decline in activities could be due to enzyme inactivation or denaturation. Haddar et al. [25] reported that the constant and highest protease enzyme activity was observed at a temperature between $25-60^{\circ} \mathrm{C}$ when using casein as substrate. Most reported protease enzymes presented their maximum rates in the range of $30-85^{\circ} \mathrm{C}$ [26].

The relationship between the rate of reaction and concentration of substrate depends on the affinity of the enzyme for its substrate expressed as Km of protease enzyme [27]. The higher the Vmax value, the higher the rate of catalysis of the enzyme. In this study, protease produced from $B$. megaterium isolated 
from refuse dumpsite was observed to have the best Vmax value. This suggests the enzyme to have the highest rate of substrate catalysis. On the other hand, $\mathrm{Km}$ indicates the affinity of the enzyme with its substrate. The lower the $\mathrm{Km}$ value the greater the affinity of the enzyme for its substrate. Protease produced from $B$. subtilis isolated from domestic waste dumpsite was recorded to have the lowest $\mathrm{K}_{\mathrm{m}}$ value. This indicates that this enzyme has the best affinity for casein substrate. Ahmed et al. [26] reported that the catalytic properties, $\mathrm{K}_{\mathrm{m}}$ and $\mathrm{V}_{\max }$ values of alkaline protease from Bacillus subtilis were $58 \mu \mathrm{M}$ and $148 \mathrm{U} / \mathrm{mL}$, respectively.

\subsection{Conclusion}

From the results recorded in this study, it is concluded that abattoir dumpsite, refuse dumpsite, domestic dumpsite and cow rumen ingesta are good sources of protease producing isolates. The results also suggest abattoir soil is the most preferable source of protease producing isolate over other dumpsites investigated in this study. The alkaline proteases produced by the isolates in this study suggests their industrial applications in leather processing, detergent industries, food industries and pharmaceutical industries.

Acknowledgement: Our appreciation goes to all the lecturers of the Biochemistry and Microbiology Departments, Federal University of Technology Minna, Nigeria

Author's contributions: T.A.N: Study design; methodology; data collection, original draft writing. E.C.E: Supervisor; reviewed draft and edited the manuscript. O.K.S and O.S.B. Co-supervised the work, reviewed draft and edited the manuscript. All authors read and approved the final version of the manuscript

Conflict of interest statement: The authors hereby declare that there is no conflict of interest from any of them.

Funding: This work received no external funding

Institutional Review Board Statement: Not Applicable.

Informed Consent Statement: Not Applicable.

\section{References}

1. BCC-Business Communications Company Research, Inc., (2011). In: Report Global Markets for Enzymes in Industrial Applications, BIO030G.

2. Arunachalam, C.; Saritha, K. Protease enzyme: an eco-friendly alternative for leather industry. Indian Journal of Science and Technology 2009, 2, 29-32.

3. Mazzucotelli, A., Durruty. I, Kotlar, C.E., Moreira, R, Ponce A. G., Roura S.I. (2014) Development of a microbial consortium for dairy waste water treatment Biotechnology and Bioprocess engineering Volume 19, Issue 2, pp. 221-230.

4. Kandasamy, S.; Muthusamy, G.; Balakrishnan, S.; Duraisamy, S.; Thangasamy, S.; Seralathan, K.-K.; Chinnappan, S. Optimization of protease production from surface-modified coffee pulp waste and corncobs using Bacillus sp. by SSF. 3 Biotech 2016, 6, 1-11.

5. Rani, K., Rana, R., and Datt, S. (2012). Review on latest overview of proteases. Int. J. Curr. Life Sci. 2, 12-18.

6. Singh, S., \& Bajaj B.K. (2017). Agroindustrial/forestry residues as substrates for production of thermoactive alkaline protease from Bacillus licheniformis K-3 having multifaceted hydrolytic potential. WastE Biomass Valoriz 8:453-462

7. Chen, X.G., Stabnikova, O., Tay, J.H., Wang, J.Y. and Tay, S.T.L., 2004. Thermoactive extracellular proteases of Geobacillus caldoproteolyticus, sp. nov., from sewage sludge. Extremophiles, 8(6), pp.489-498.

8. Badhe, P., Joshi, M. and Adivarekar, R., 2016. Optimized production of extracellular proteases by Bacillus subtilis from degraded abattoir waste. Journal of BioScience \& Biotechnology, 5(1). 
9. Bharathiraja, S., Suriya, J., Krishnan, M., Manivasagan, P. and Kim, S.K., 2017. Production of enzymes from agricultural wastes and their potential industrial applications. In Advances in food and nutrition research (Vol. 80, pp. 125-148). Academic Press.

10. Williams, J.O. and Hakam, K. (2015). Microorganisms associated with dump sites in Port Harcourt Metropolis, Nigeria. journal of ecological and natural environment. Vol. 8(2), pp. 9-12

11. Varjani, S.J., Gnansounou, E. and Pandey, A., 2017. Comprehensive review on toxicity of persistent organic pollutants from petroleum refinery waste and their degradation by microorganisms. Chemosphere, 188, pp.280-291.

12. Melikoglu, M., Lin, C.S.K., Webb, C. (2015). Food Bioprod. Process. 95, 63-75.

13. Christy, P.M., Gopinath, L.R. and Divya, D., 2014. A review on anaerobic decomposition and enhancement of biogas production through enzymes and microorganisms. Renewable and Sustainable Energy Reviews, 34, pp.167-173.

14. Makut, M.D., and Ibrahim, M.Z. (2021). Molecular and phylogenic identifications of potential herbicide degrading microorganisms from contaminated farmland in Keffi, Nasarawa State, Nigeria. AROC in Pharmaceutical and Biotechnology, 01(01);17-25

15. Makut, M.; Ekeleme, I. Citric Acid Production by Aspergillus niger and Trichoderma viride Using Hydrolysed Potato Peels Substrate. Asian Journal of Advances in Agricultural Research 2018, 17

16. Massaoud, M.K., Marokházi, J., Fodor, A. and Venekei, I., 2010. Proteolytic enzyme production by strains of the insect pathogen Xenorhabdus and characterization of an early-log-phasesecreted protease as a potential virulence factor. Applied and environmental microbiology, 76(20), pp.6901-6909.

17. Arunachalam, C. and Saritha K. (2009). Protease enzyme: An eco-friendly alternative for leather industry. Indian journal of science and technology. 2(12), 98-103.

18. Joo, H. S., C. G. Kumar, G. C. Park, K. T. Kim, S. R. Paik, \& C. S. Chang (2002). "Optimization of the production of an extracellular alkaline protease from Bacillus horikoshii," Process Biochemistry, vol. 38, no. 2, pp. 155-159.

19. Gill, J., Rahman H, Rahman, Y. (2016). Isolation and Characterization of effective bacteria for solid waste degradation for organic manure", KMITL, Sci Tech J 8(2): 844-855, 2008.

20. Anila, H., Gomez, A., Herrera, X, (2013). Characterization of microbial diversity at different depths in the Moravia Hill landfill site at Medellín, Colombia. Soil Biol. Biochem. 43, 1275-1284

21. Emimol, A., Ganga, G., Parvathy, R., Radhika, G. and Nair, G.M., 2012. Screening of microbes producing extracellular hydrolytic enzyme from corporation waste dumping site and house hold waste for the enhancement of bioremediation methods. IOSR-JPBS, 4, pp.54-60.

22. Kocabiyik, S., and Ozdemir, I. (2006). Purification and characterization of an intracellular chymotrypsin-like serine protease from Thermoplasma volcanium. Biosci. Biotechnol. Biochem. 70(1):126-134.

23. Miyaji, T., Otta, Y., Nakagawa, T., Watanabe, T., Niimura, Y., Tomizuka, N. (2006). Purification and molecular characterization of subtilisin-like alkaline protease BPP-A from Bacillus pumilus strain MS-1. Lett. Appl. Microbiol. 42(3):242-247.

24. Vidyasagar, M., Prakash, S.B., Sreeramulu, K. (2006). Optimization of culture conditions for the production of haloalkaliphilic thermostable protease from an extremely halophilic archaeon Halogeometricum sp. TSS101. Lett. Appl. Microbiol. 43:385-391.

25. Haddar, A., Agrebi, R., Bougatef, A., Hmidet, N., Sellami-Kamoun, A. (2009) Two detergent stable alkaline serine-proteases from Bacillus mojavensis A21: purification, characterization and potential application as a laundry detergent additive. Bioresour Technol 100: 3366-3373. 
26. Ahmed, I., Zia, M.A., Iqbal, H.M.N (2011). Purification and kinetic parameters characterization of an alkaline protease produced from Bacillus subtilis through submerged fermentation technique. World Applied Sciences Journal 12: 751-757.

27. Arulmani, M., Aparanjini, K., Vasanthi, K., Arumugam, P., Arivuchelvi, M. (2007). Purification and partial characterization of serine protease from thermostable alkalophilic Bacillus laterosporus- AK1. World J Microbiol Biotechnol 23: 475-481.

\section{Submit your article to AROC JOURNALS \\ -AROC in Pharmaceutical and \\ Biotechnology \\ -AROC in Agriculture \\ -AROC in Bioinformatics \\ -AROC in Food and Nutrition \\ -AROC in Natural Product Research \\ -BIOMED Natural and Applied Science}

Copyright $\odot 2021$ Tsado et al. This is an open access article distributed under the terms and conditions of the Creative Commons Attribution License (CC BY) which allowed unrestricted download, distribution and reused as long as the original authors are properly cited.

BIOMED Natural and Applied Science 2021;1(2):45-53

ISSN: $2789-178 \mathrm{X}$ 